\title{
4
}

\section{RISING INEQUALITY AMID RAPID GROWTH IN ASIA AND IMPLICATIONS FOR POLICY ${ }^{1}$}

Juzhong Zhuang

\section{Introduction}

Over the past three decades, developing Asia achieved economic growth and reduced poverty faster than any other region of the world at any time in history. But the bulk of the region's population lives in countries with rising income inequality. This is in contrast with the 'growth with equity' story that marked the transformation of the newly industrialised economies in the 1960s and 1970s, and with recent trends in some other parts of the developing world, particularly Latin America, where income inequality has been narrowing since the 1990s.

Technological change, globalisation, and market-oriented deregulation have driven Asia's rapid growth, but have also had significant distributional implications. These forces tend to favour owners of capital over labour, skilled over unskilled workers, and urban and coastal areas over rural and inland regions. The impacts of these forces have been compounded by

1 Views expressed in the paper are those of the author and do not necessarily reflect views and policies of the Asian Development Bank or its Board of Governors or the governments they represent. 
various forms of unequal access to opportunity caused by institutional weaknesses and social exclusion. Working together, these have led to a falling share of labour income in total national income, increasing premiums on human capital, growing spatial disparity, and widening wealth inequality - all contributing to rising income inequality.

How should Asian governments respond to rising inequality? The three driving forces of economic growth should not be obstructed even though they cause rising inequality. But it is important for Asian policymakers to deploy policy measures to confront rising inequality, focusing on equalising opportunity, which reduces income inequality. These policies include measures toward creating more high-quality jobs for a wider population, interventions that narrow spatial disparity, fiscal policies that reduce inequality in human capital and that make the tax system effective and fairer, and reforms that strengthen governance, level the playing field, and eliminate social exclusion.

\section{Recent trends of inequality in developing Asia}

Many countries in Asia and the Pacific have seen remarkable achievements in growth and poverty reduction in the last three decades. From 1990 to 2017, the average annual growth rate of gross domestic product (GDP) for developing Asia reached 7 per cent in 2011 purchasing power parity (PPP) terms, more than double the 2.8 per cent of Latin America and the Caribbean (Figure 4.1). Much of the growth was driven by the People's Republic of China (PRC) and India - the world's two most populous countries - with annual GDP growth during the period reaching 9.7 per cent and 6.7 per cent, respectively.

The rapid growth has dramatically improved living standards of Asian people and reduced extreme poverty. During 1990-2017, the region's average per capita GDP in 2011 PPP terms increased from \$2,423 to $\$ 10,725$. The proportion of the population living on or below the \$1.9-a-day poverty line fell from 53 per cent in 1990 to around 9 per cent in 2013, as over one billion people were lifted out of poverty. Fifteen countries reduced poverty by more than 15 percentage points in the period. 


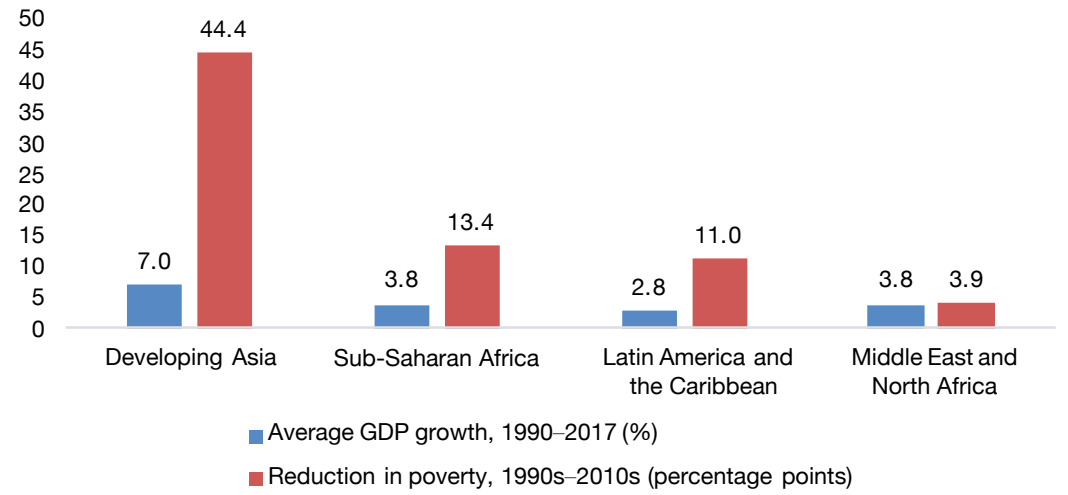

Figure 4.1. Annual GDP growth and cumulative poverty reduction

Source. Asian Development Bank, Asian Development Outlook database; World Bank, World Development Indicators online database; International Monetary Fund, World Economic Outlook October 2017 database (accessed 10 January 2018)

This performance in growth and poverty reduction has, however, been accompanied by rising income inequality in many countries. Of the 30 countries that have comparative data between the 1990s and early 2010s, nine - accounting for more than 80 per cent of developing Asia's population in 2016 - experienced rising inequality (Figure 4.2). The Gini coefficient of per capita expenditure - a common measure of inequality with zero indicating perfect equality and 100 perfect inequality ${ }^{2}$ - worsened in the nine economies, including the three most populous countries - the PRC, India, and Indonesia. From the early 1990s to 2013, the Gini increased from 32 to 40 in the PRC, from 32 to 35 in India, and from 31 to 38 in Indonesia. In the PRC, the Gini coefficient has declined slightly since 2008, but the level remains among the highest in Asia (Zhuang \& Shi 2016).

Although Asia's inequality levels are generally below those in other developing regions - developing Asia's range of the Gini coefficients is 2646 with a median of 37 in 2013, compared with 31-63 and the median of 43 for sub-Saharan Africa, and 40-58 and the median of 47 for Latin America and the Caribbean - inequality declined elsewhere, with the exception of Organisation for Economic Co-operation and Development (OECD) countries (Table 4.1). The majority of OECD countries - with the Gini in the range of 25-47 and the median of 32 - also experienced rising inequality in the last three decades.

2 A common measure of inequality, ranging from zero indicating perfect equality and one indicating perfect inequality. For convenience, this note cites the Gini multiplied by 100 . 


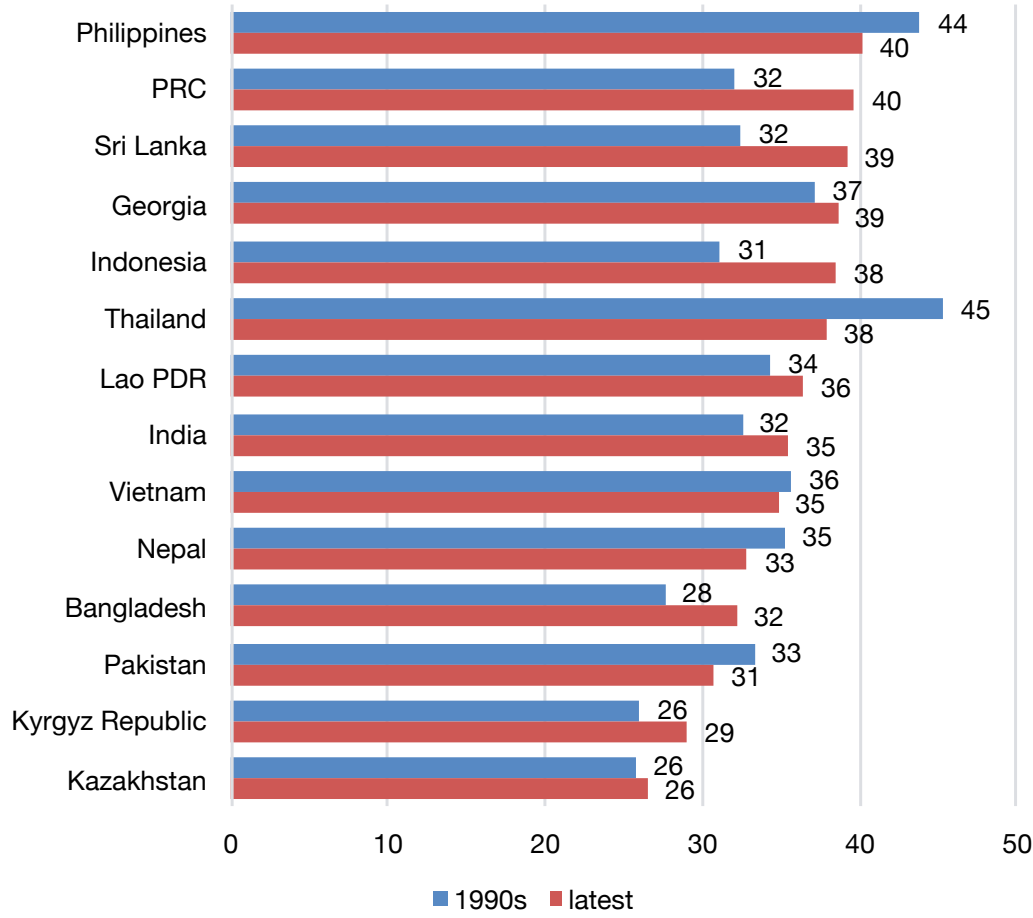

Figure 4.2. Gini coefficient, selected Asian economies, 1990s and 2013 or latest

Source. PovCal Database, World Bank (accessed 11 October 2017)

\section{Table 4.1. Gini coefficients by region}

\begin{tabular}{|l|c|c|c|c|c|c|}
\hline & \multicolumn{3}{|c|}{1981} & \multicolumn{3}{c|}{2013} \\
\cline { 2 - 7 } & Minimum & Maximum & Median & Minimum & Maximum & Median \\
\hline Developing Asia & 25 & 55 & 37 & 26 & 46 & 37 \\
\hline OECD & 19 & 56 & 31 & 25 & 47 & 32 \\
\hline $\begin{array}{l}\text { Latin America and } \\
\text { the Caribbean }\end{array}$ & 41 & 60 & 49 & 40 & 58 & 47 \\
\hline $\begin{array}{l}\text { Middle East and } \\
\text { North Africa }\end{array}$ & 29 & 47 & 38 & 28 & 44 & 35 \\
\hline $\begin{array}{l}\text { Sub-Saharan } \\
\text { Africa }\end{array}$ & 32 & 66 & 45 & 31 & 63 & 43 \\
\hline
\end{tabular}

Note. The Gini coefficients are based on per capita expenditure for developing Asia and sub-Saharan Africa and per capita disposable income for Latin America and the Caribbean and OECD countries. Income-based Gini coefficients are normally higher than expenditurebased Gini coefficients, and the difference is in the range of 5-10.

Source. PovCal database, World Bank (accessed 11 October 2017) 
Inequality of opportunity is also prevalent in developing Asia, and is a crucial factor in widening income inequality (Son 2012). Disparities in the means to raise one's living standards - such as physical assets (e.g. capital and land), human capital (e.g. education and health), and market access (e.g. labour and finance) - are common. Unequal access to public services, especially education and health, is central to generating inequality of opportunity. National household surveys conducted in the mid- to late-2000s revealed facets of diverging opportunities in many developing Asian countries. For instance, school-age children from households in the poorest income quintile were three to five times as likely to be out of primary and secondary school as their peers in the richest quintile in some countries. The situation was even more dire for tertiary education as poorer college-age individuals were 10-20 times more likely not to attend college than their better off peers.

Similarly, infant mortality rates among the poorest households in some countries were double or treble the rates among the richest households. In the most extreme examples, the chance of a poor infant dying at birth was more than 10 times higher than for an infant born to a rich family. With few exceptions, the region's economies have made significant progress toward gender parity in primary and secondary education. Yet high gender disparities in tertiary education remain in South Asia and the Pacific. Inequality of opportunity and of income can lead to a vicious circle, as unequal opportunities create income disparities, which in turn lead to differences in future opportunities for individuals and households.

\section{Why inequality matters}

Rising inequality hampers poverty reduction. Each percentage of economic growth will generate a lower rate of poverty reduction when inequality is increasing than when inequality remains unchanged or is decreasing.

Inequality can weaken the basis of growth itself. High and rising inequality can affect growth through a number of economic, social, and political mechanisms. Inequality of wealth and income can lead to a misallocation of human capital. Those with little wealth or low income are unable to invest in human capital, or wealth- and income-enhancing activities, and will remain poor. In principle they may be able to borrow to finance investment. But imperfect financial markets, coupled with other market failures, often heavily constrain their ability to borrow and invest. 
Widening inequality - leaving more people at the top and bottom of the ladder - can mean a hollowing out of the middle class. It has been argued that growth driven by and benefiting a middle class is more likely to be sustained - both economically, to the extent that the rent seeking and corruption associated with highly concentrated gains to growth are avoided, and politically, to the extent that conflict and horizontal inequalities between racial and ethnic groups are easier to manage.

In fact, there is a broad consensus among researchers on the link between inequality and the quality of institutions. Along several dimensions, ranging from political stability, through institutional stability, to property rights, the negative impact of inequality on institutional quality seems to be well established, although the two-way causality is also widely recognised (Zhuang et al. 2010; Nye 2014). At the same time, there is also a literature on the effect of inequality on crime and violence and, through that, on the investment climate (Fajnzylber et al. 2002; Ozler \& Demombynes 2002).

Finally, greater inequality may lead to a political backlash and growing pressure for governments to enact populist policy measures. In response to rising demands, the political process may favour policies that, in the short term, would benefit the lower end of income distribution, but which in the long run could hold back efficiency and growth. Under such conditions, the interests of the political system diverge from the interests of the economy as a whole. This is a widespread concern in developing and developed countries alike.

Asian policymakers are becoming more concerned about inequality. In an informal web-based survey of Asian policymakers, ${ }^{3}$ about two-thirds of the respondents indicated that the level of income inequality is high or very high and that it has increased from 10 years ago; three-quarters of the respondents indicated that the level of concern over inequality among policymakers has increased; almost all the respondents thought that it is important or very important to have policies in place to prevent rises in inequality in order to maintain stability and sustain growth; and more than half believed that success in reducing poverty was insufficient to justify widening inequality.

3 The survey was carried out by Asian Development Bank (ADB) in January-February 2012. From key government agencies in 25 of the ADB's developing member countries, 504 respondents registered their opinions. 
Asian governments are responding to this concern, which is increasingly being addressed through development plans across the region that include explicit goals to make growth more inclusive. In India, the government made an explicit commitment to inclusive growth in its recent successive five-year plans. In the PRC, the authorities set about building a harmonious society, scientific development, and realising the Chinese dream as the development goals and have committed to making growth inclusive. In Indonesia, Malaysia and the Philippines, inclusive growth or development is at the heart of their current medium-term development strategies.

The distinction between inequality of opportunity and inequality of outcome is important in guiding public policy. Inequality of opportunity - access to education, health, public services or jobs - often arises from differences in individual circumstances that are outside the control of individuals - such as gender, ethnic origin, parental education or birth location. Such inequality largely reflects institutional weaknesses and social exclusion, and should be the target of public policy. On the other hand, given an individual's circumstances, what the individual chooses for effort in the labour market or in education will also influence his or her outcomes - such as income or consumption. Inequality of outcomes arising from differences in individual effort reflects and reinforces the market-based incentives that are needed to foster innovation and growth. This distinction is something of which the general public and policymakers in Asia are aware, as shown by the results from the World Values Survey (2005) and the Asian Development Bank's (ADB) web-based survey of Asian policy makers (ADB 2012). ${ }^{4}$

\footnotetext{
4 The 2005 World Values Survey asked representative samples of people in 69 countries to locate their views on a scale of 1 to 10 , with 1 meaning 'incomes should be made more equal' and 10 meaning 'we need larger income differences as incentives'. The Asian responses are more skewed toward 10 - about 63 per cent of the responses are in the 6-10 range - although there is still significant weight in the lower value responses. In comparison, the OECD responses are spread more evenly over the 10 categories. Results from ADB's web-based survey indicate that about 60 per cent of the respondents agree or strongly agree with the statement that it is more important to reduce inequality of opportunity (such as access to education, health and employment services) than to reduce inequality of income.
} 


\section{What drives Asia's rising income inequality?}

\section{Conceptual discussion}

Total income of a household is the sum of its income derived from labour and that derived from capital:

$$
\text { Income }=W L+R K
$$

Capital income is the product of the different types of capital assets $(K)$ owned by the household and their respective rates of return $(R)$. For a typical household, capital assets consist mostly of housing, land, factories and machinery, and financial assets. Labour income - which includes returns to human capital - is the product of the different types of labour assets $(L)$ and their respective wage rates $(W)$. The return to human capital is reflected in the skill premium; that is, the more educated and skilled labourer earns higher wages. $K, R, L$, and $W$ can all be considered as vectors. Income inequality estimates are usually based on per capita household income (where $H$ is the total number of households), that is:

$$
\frac{\text { Income }}{H}=W\left(\frac{L}{H}\right)+R\left(\frac{K}{H}\right)
$$

Therefore, inequality in per capita household income is the result of inequality in per capita labour income $(L W / H)$, inequality in per capita capital income $(K R / H)$ and the relative importance of labour and (non-human) capital incomes (WL Income) and RKIIncome, respectively) in total household income. ${ }^{5}$ Changes in income inequality can be thought of as resulting from a combination of changes in the distributions of assets, changes in the relative returns to these assets, and changes in the relative importance of labour and capital incomes in total household income.

In any society, the distribution of non-human capital reflects its ownership structure, while the distribution of human capital is determined mostly by inequality in access to education and health services. Over time, many factors shape these distributions, including initial distributions, household savings behaviour and investment decisions, differences in individual

5 Lerman and Yitzhaki (1985) decompose the Gini coefficient into the contributions by income source. Each source's contribution to overall inequality is the product of its Gini coefficient, its share in total income, and its correlation with the rank of total income. 
effort and entrepreneurship, political economy factors (such as pressures for land redistribution, taxation on wealth, and public spending on human capital), the quality of governance and institutions, and demographics.

Changes in the relative returns to assets reflect demand and supply conditions in the marketplace and how efficiently the market works - for instance, the presence or absence of monopoly or discrimination against particular population groups (such as females or rural residents), and political economy factors (such as labour market institutions and taxation on labour and capital incomes).

Finally, changes in the relative importance of labour and capital incomes in total household income are determined by the relative changes in returns to labour and capital and in the capital-labour ratio. These are in turn determined by technological advances and the bias of technical progress, the relative bargaining positions of labour and capital, political economy factors such as labour market institutions (minimum wages, collective bargaining and employment protection), taxation, and the presence or absence of market distortions.

Within this framework, income inequality increases if changes in relative returns to assets or in the distribution of assets, or in the relative importance of labour and capital incomes in total income, favour the better-off households. There are many ways in which this could happen.

First, wage rates could increase faster for better educated and skilled workers than for the less educated and skilled. There is a large literature showing that globalisation and technological progress may have increased the demand for skilled workers relative to that for unskilled workers in many developing countries, leading to an increasing skill premium (ADB 2012). In the case of the PRC, the market-oriented reforms introduced after 1979 dismantled the fixed-wage system that existed under central planning and made wages more reflective of workers' skills and educational attainments and of market demand and supply conditions, and may have also contributed to the increase in the skill premium.

Second, the differential in the returns to capital and in wage rates between richer coastal and urban areas and the poorer interior and rural areas could increase as growth accelerated, leading to increasing spatial inequality. This is because coastal regions are closer to trade routes and world markets than interior regions; and, because cities have better infrastructure than rural areas, they are more likely to attract investment and new technologies, 
especially during the initial phase of growth take-off (Lewis 1954). All these factors could lead to greater increases in productivity, wages and returns to capital assets in the favoured areas. In the PRC, for example, land and housing prices have increased much faster in coastal areas and cities than in inland provinces and rural areas in the last 30 years or so.

Third, capital income could increase faster than labour income. This would lead to a rising share of capital income in total household income (which tends to be less equally distributed and mostly earned by richer households) and a declining share of labour income (which tends to be more equally distributed and more important for poorer households). This occurs when total income grows faster than total labour income, leaving a larger share of income accruing to capital. ${ }^{6}$ It has been suggested that technological progress, especially the adoption of information and communications technology (ICT) and automation, has reduced the demand for labour relative to that for capital (as shown by a declining employment elasticity of growth in recent decades), thus favouring capital. In some countries, the large pool of rural surplus labour has also put downward pressure on urban wage rates (until recently in the case of the PRC).

Fourth, increasing inequality in asset distribution can also lead to an increase in income inequality. Inequality in human capital could increase if wealthier households invest more in education and health than poorer households. Inequality in capital assets could increase if wealthier households save more, if they receive higher returns to capital due to economies of scale or if they have lower fertility rates than less wealthy households.

In addition to these major drivers, there are other reasons why income inequality could increase. One is increases in corruption and rent-seeking, if better off households are more likely to engage in such activities. Another source is the remittances sent home (mostly in rural areas) by migrant workers working in urban areas, which may increase inequality in rural areas but nevertheless reduce urban-rural income gaps.

6 Alternatively, the share of labour income can decline and that of capital increase when the rate of return to capital grows faster, or decreases more slowly, than the output-capital ratio. It is easy to show that the capital-output ratio equals the ratio of the savings rate (s) to the growth rate of the capital stock. In a steady state, the latter equals the growth rate of output (g), which implies that capitalincome share is the ratio of the product of the rate of return to capital times the savings rate $(\mathrm{r} s)$ to the growth rate $(\mathrm{g})$. This means that, assuming a constant savings rate, capital-income share will increase as the gap between $r$ and $g$ increases. And likewise, assuming a constant ratio $(r / g)$, a higher saving rate will lead to a higher capital share. 


\section{Empirical evidence}

Technological progress, globalisation, and market-oriented deregulation have been the key drivers of developing Asia's rapid growth in the last several decades - but they have also had huge distributional implications. Together, they have favoured skilled over unskilled labour, leading to a rising skill premium; capital over labour, leading to a rising share of capital income; and urban and coastal areas over rural and inland regions, leading to rising spatial inequality. These forces can explain a large part of the movements in income distribution and inequality in many countries in Asia. In the PRC, evidence shows that rising income inequality has also led to rising wealth inequality, which in turn increases income inequality.

\section{Rising skill premiums}

There is significant global evidence that the rates of return to progressively higher levels of education have been trending upward in recent years. In OECD countries, for instance, those who do not complete an upper secondary education could earn an average of 23 per cent less than their counterparts who do. A person with a tertiary education can expect to earn over 50 per cent more than a person with an upper secondary or post-secondary non-tertiary education (OECD 2011).

In Asia, empirical studies find that the returns from education increase with educational attainment and that the relationship has been getting steeper over time. An ADB study (2007) found that from the mid-1990s to mid-2000s, real wages in India and the Philippines grew much faster for wage earners with tertiary or higher education than for those with lower educational attainment, leading to wider wage differentials. The same study also found that education is the single-most important factor among those variables that were included in analysing wage inequality. In the case of India, the Gini coefficient of wages increased from 40.5 in 1993 to 47.2 in 2004 . Half the increase can be explained by individual characteristics. Of this explained increase, about 50 per cent is accounted for by education.

Many other studies have provided direct or indirect evidence of rising skill and/or education premiums in developing Asia. Son (2010) found that education increases individuals' employability in the Philippines. A study on India, the Philippines and Thailand found that the rate of return to college education rose relative to that of secondary education between the mid-1990s and mid-2000s (Mehta et al. 2011). This rise was related to 
the expansion of high-skill service jobs that, while they employed only 7-11 per cent of the labour force, contributed $40-70$ per cent of the rate of return to college education.

A World Bank study (World Bank 2012) reported that the tertiary education premium ${ }^{7}$ stood at 90 per cent for Cambodia (2007), 60 per cent for the PRC (2005), 84 per cent for Indonesia (2007), 70 per cent for Mongolia (2007), 70 per cent for the Philippines (2006), 120 per cent for Thailand (2004) and 55 per cent for Vietnam (2006). In Cambodia, the PRC, Mongolia and Vietnam, the premium has increased in recent years across sectors. The tertiary education premium increased in Indonesia in the manufacturing sector and in the Philippines in the services sector.

Household survey data help reveal patterns of income inequality due to educational attainment (in this case, of the household head) (Figure 4.3). First, education inequality almost always accounts for more than 20 per cent of total income inequality. Second, the share of total income inequality explained by educational inequality has by and large been on the increase. The share of inequality accounted for by differences in educational attainment increased in all the countries during the periods reviewed, with the increase most significant in the PRC, from 8.1 per cent in 1995 to 26.5 per cent in 2007.

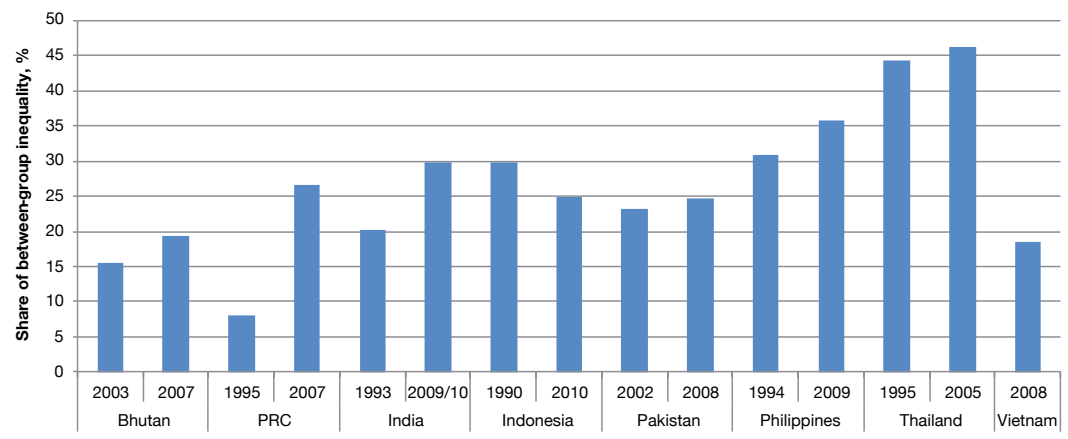

Figure 4.3. Income inequality decomposition by educational attainment PRC $=$ People's Republic of China.

Note. Estimates are based on per-capita expenditure in nominal terms, except for the $\mathrm{PRC}$ which is based on income. The decomposition is based on GE(0), which is a special form of the generalised entropy index.

Source. The author's estimates using household survey data from ADB

7 Tertiary education premium refers to the wage premium for workers with at least tertiary education compared with workers with a lower level of education. 
As in the rest of the world, developing Asia is facing strong upward pressure on the wage gap between skilled and unskilled labour. Is this because of skill-biased technological progress? There are empirical difficulties in isolating this factor because the wage premium depends on both demand-and supply-side factors. Unsurprisingly, analysts have come down on both sides of the explanation. ${ }^{8}$ To the extent that skill-biased technological change happens, its impact can be transmitted through globalisation. It is unlikely that policymakers can reverse this trend, nor should they want to, since technological progress is delivering higher levels of productivity and growth in the economy. The answer, rather, is to address inequality in human capital itself.

\section{Labour's falling share of total income}

In the last several decades, the income share of labour has been on the decline and that of capital on the rise in many countries around the world. In the United States, for example, the labour-income share in industry declined from 65 per cent in 1992 to 52.4 per cent in 2009. Similarly, in Germany, the labour-income share of industry peaked at 79.5 per cent in 1993 from the rise that started in the mid-1980s, declining since then.

A declining labour-income share means that the growth of real wage rates lags behind growth of labour productivity. A number of contributing factors have been identified in the context of the developed world. The first is that technological change, especially connected with improvements in information and communication technologies and automation, has raised the productivity of and return to capital relative to labour. The second is the decrease in the bargaining power of labour, due to changing labour market policies and declining union membership in these countries. The third is increased globalisation and trade openness, which led to migration of relatively more labour-intensive sectors from advanced economies to emerging economies - with the sectors remaining in the

8 Acemoglu (2002) noted that, for the late-twentieth century, there has been a rise in returns to education and a decrease in low-skill wages, despite an increase in the supply of college graduates, which suggests that supply has not kept up with demand for high-skilled labour. Studies have also argued for evidence of skill-biased technological change in developing countries (Goldberg \& Pavcnik 2007; Robbins 1996; Sanchez-Paramo \& Schady 2003; and Attanasio, Goldberg \& Pavcnik 2004 for Latin America; Hsieh \& Woo 2005 for Hong Kong, China; and Kijima 2006 for India). However, Card and DiNardo (2002) pointed out that wage inequality stabilised in the United States despite continuing developments in computer technology. They also argued that skill-biased technological change does not fully explain wage gaps across genders, and racial and demographic structures. The debate between competing explanations for the United States is ongoing (see Autor, Katz \& Kearney 2008; Marquis, Trehan \& Tantivong 2011). 
advanced economies being relatively less labour-intensive and having a lower average share of labour income (Jacobson \& Occhino 2012; Arpaia et al. 2009). It has also been noted that globalisation and trade openness increase the elasticity of labour demand, which also weakens labour's bargaining position (Rodrik 1997; Harrison 2002).

Empirical evidence suggests that Asia is following this trend - all the economies in Figure 4.4 saw declines in labour-income shares during the mid-1990s to mid-2000s. What are the causes of these declines? Technological progress in the region appears to have been labour-saving and capital-using. Partly, this can be explained by a high level of capital accumulation in many Asian countries (Felipe 2009). As a result, the wage employment elasticity of growth ${ }^{9}$ has been on the decline in many countries in recent years - for example, in the PRC from 0.44 in 19912001 to 0.28 in $2001-11$ and in India from 0.53 to 0.41 for the same period. This decline means that each percentage of employment growth now requires a higher percentage of output growth than in the past a phenomenon sometimes referred to as 'jobless growth' (ADB 2012).

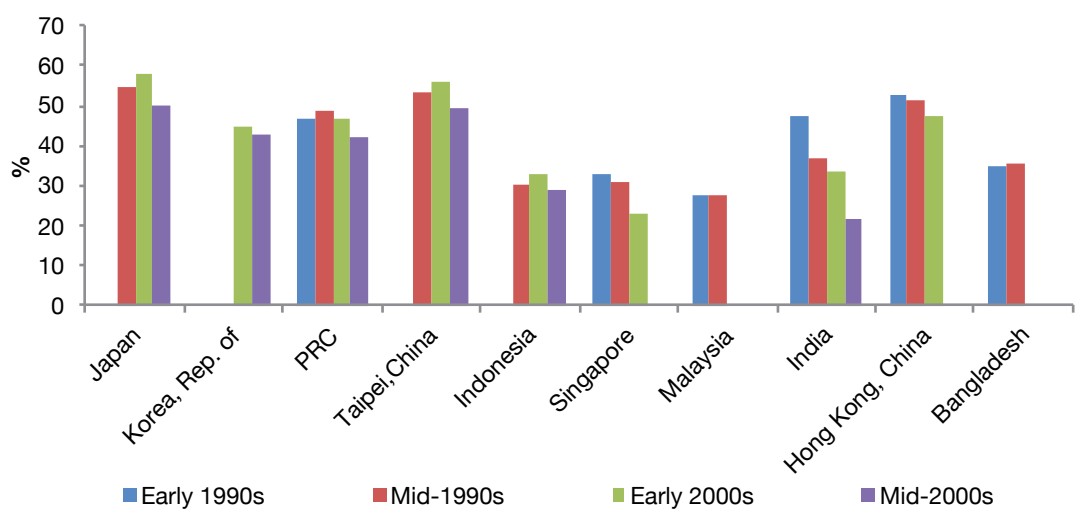

Figure 4.4. Share of labour income in industrial value added, selected Asian economies

Note. Early 1990s (1990-92), mid-1990s (1994-96), early 2000s (2000-02), and mid-2000s (2004-06) for the PRC; India; Singapore; Malaysia; India; Hong Kong, China; and Bangladesh.

Source. OECD.Stat database (OECD 2018) for Japan; Republic of Korea; Taipei, China; and Indonesia (accessed 1 March 2012); Felipe \& Sipin (2004) for Singapore; Malaysia; Hong Kong, China; and Bangladesh; Bai \& Qian (2009) for the PRC; and Felipe \& Kumar (2010) for India's organised manufacturing sector

9 Wage employment refers to wage-earning employment, mostly in the formal sector. Wage employment elasticity is the ratio of employment growth to GDP growth between two periods. It thus measures the amount of employment growth required to generate each percentage point of GDP growth. 
A declining employment elasticity of growth implies increases in labour productivity. Annual growth of manufacturing labour productivity in 2000-08 reached 6.7 per cent in the PRC and 5.5 per cent in Malaysia, and was in the range of 3-4 per cent in Indonesia, Pakistan, the Philippines, Thailand and Vietnam (Asian Productivity Organization 2011).

That labour productivity is increasing but labour income share is declining implies that real wage growth has lagged behind labour productivity growth, partly because of the presence of a large pool of surplus rural labour in many countries associated with their dual-economy structure. The surplus labour pool weakens the bargaining power of labour and depresses wages in the non-agriculture sectors, contributing to declines in the labourincome share when globalisation and market-oriented reform led to rapid growth. In India, for instance, average annual growth of labour productivity was 7.4 per cent in 1990-2007, while average annual real wage growth was only 2 per cent. In the case of the PRC, Zhuang (1996) showed that if the labour market had been fully liberalised and controls over labour transfer from rural to urban areas fully relaxed in the early 1980s, urban wage rates would have fallen, and the labour-income share of the urban sector would have decreased by half. A lower share of income going to labour and a higher share of income going to capital tends to increase inequality, because capital income is mostly earned by richer households and more unequally distributed than income from basic wage labour.

\section{Increasing spatial inequality}

As the distribution of economic activity is structured geographically - high concentrations and incomes in some locations, and low on both counts in others - so are the distribution of income and its evolution. Some locations have natural advantages, like fertile soil for agriculture or proximity to a coastline for trade. ${ }^{10}$ Economic analysis has also highlighted the role of agglomeration benefits, where once concentration starts because of natural advantages or because of advantages conferred by infrastructure, there is a self-perpetuating process of increasing concentration (Krugman 2008).

The increasing rural-urban income gap is a significant contributor to inequality in several Asian countries (Figure 4.5), especially the PRC (around 45 per cent).

10 Several decades ago, Nobel laureate in economics Arthur Lewis pointed out the tendency of the development process to be inegalitarian: 'Development must be inegalitarian because it does not start in every part of the economy at the same time ... There may be one such enclave in an economy, or several; but at the start, development enclaves include only a small minority of the population' (Lewis 1976). 


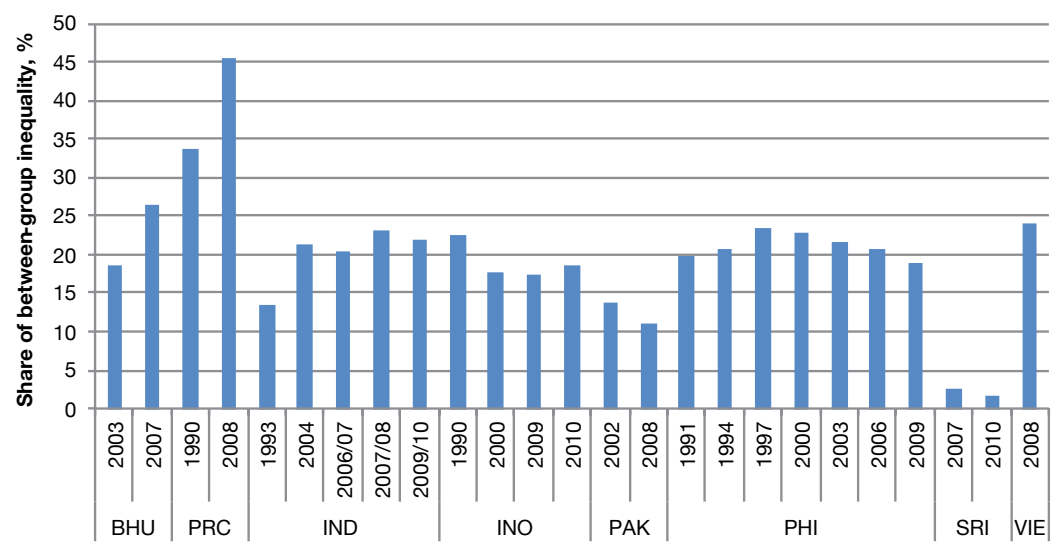

Figure 4.5. Income inequality decomposition, urban/rural

$\mathrm{BHU}=$ Bhutan, $\mathrm{IND}=$ India, $\mathrm{INO}=$ Indonesia, $\mathrm{PAK}=$ Pakistan, $\mathrm{PHI}=$ Philippines, $\mathrm{PRC}=$ People's Republic of China, SRI = Sri Lanka, VIE = Vietnam.

Note. Estimates are based on per-capita expenditure in nominal terms. Decomposition is based on $\mathrm{GE}(0)$, which is a special form of the generalised entropy index.

Source. The author's estimates using household survey data from the ADB

The possibility of rising inequality due to urbanisation as part of the development process was first pointed out by Kuznets (1955). The mechanism that he highlighted in his contribution starts with a two-sector model with the population divided between a low mean income, low inequality sector (rural/agriculture) and a high mean income, high inequality sector (urban/industrial). In this model, the drivers of inequality are changes in inequality within the two sectors, a widening of the gap between average incomes in the two sectors, and a shift of population from agriculture in the rural sector to industry in the urban sector - or the process of urbanisation.

Inequality changes within the two sectors are most likely affected by the same factors discussed in the previous sections, particularly the widening wage premium for skills, and the regional disparity (to be discussed in the next section). To the extent that the urban labour force has a higher level of human capital than the rural labour force, this factor would also tend to widen the rural-urban gap in average incomes. Perhaps the strongest driver of that gap, however, is the cumulative force of agglomeration economies and its impact on productivity (de Groot et al. 2008). For whatever combination of reasons, the rural-urban income gap in Asia has been widening in the last two decades, and it has been a driving force 
of rising inequality in the PRC (Figure 4.6). Thus the first two factors change in inequality within the two sectors and a widening of the gap in the average income between the two sectors - are likely to put upward pressure on inequality in Asian countries.

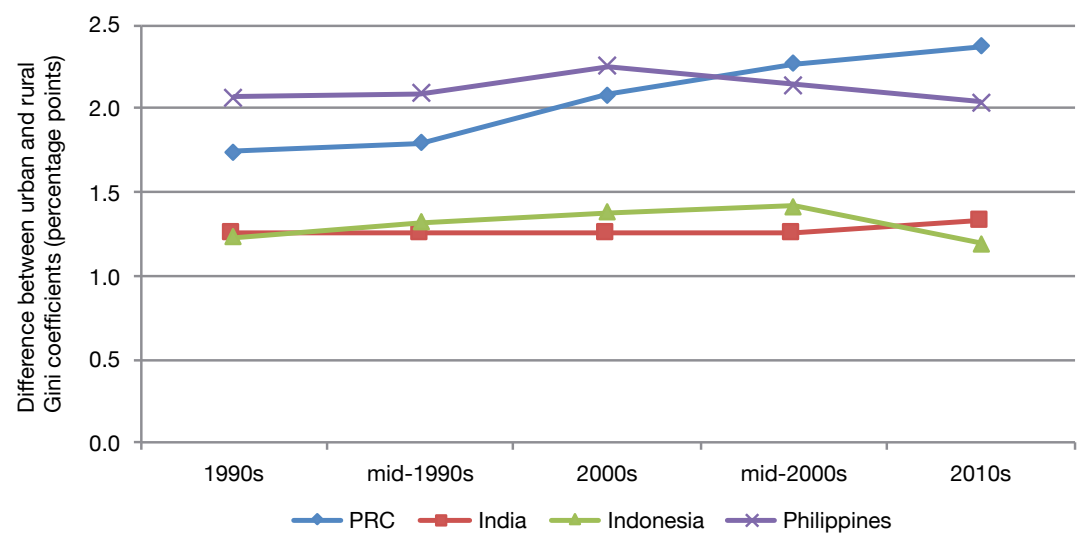

Figure 4.6. Urban-rural income gaps in selected Asian economies, 1990s-2010s

Note. Figures are for the closest available year. Missing data in India for the mid-1990s and 2000 s are assumed to be the same as the closest five-year period.

Source. The author's estimates using PovcalNet (accessed 9 March 2012)

What about the third factor? As is well known, urbanisation in Asia has been rapid. Kuznets explored this with the aid of a numerical example, which showed increasing inequality to start with as urbanisation begins, followed by a decrease at the later stages. Anand and Kanbur (1993) showed that if there is no inequality within the two sectors, with the only difference between them being because of the higher income in the urban area, then inequality will indeed follow an inverse U-shape, so that this driver will tend to raise inequality in the early stages of urbanisation. Further, if urban inequality is higher than rural inequality, this effect will be reinforced. Kanbur and Zhuang (2013) find that, during the period from the early 1990s to the late 2000s, urbanisation can explain about 54 per cent of the increase in inequality in Indonesia and 14 per cent in India, but helped reduce inequality in the PRC. 


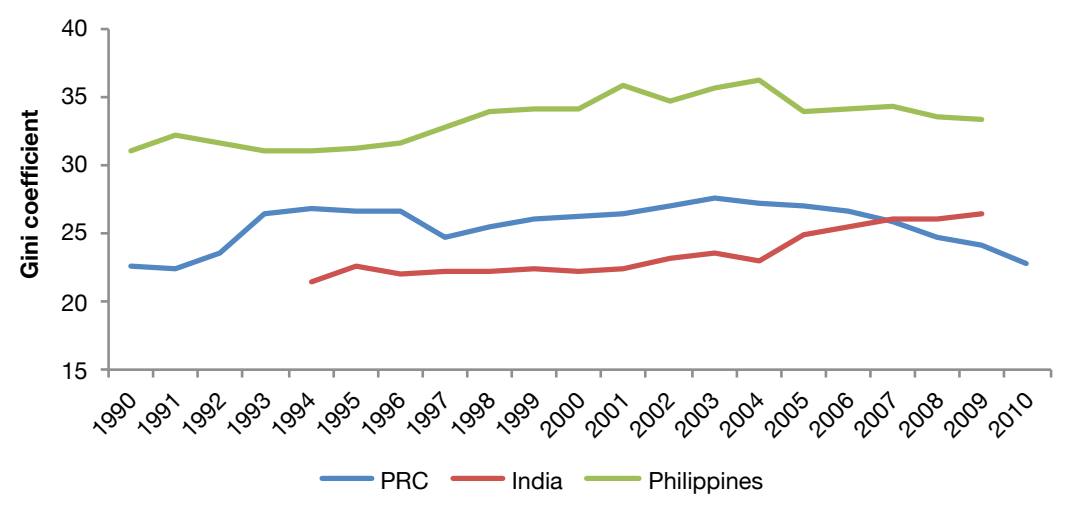

Figure 4.7. Inequalities in provincial per capita incomes in selected Asian economies, 1990-2010

Note. Gini coefficients are weighted by group population.

Source. The author's estimates using province-level data for the PRC and the Philippines from the CEIC database (accessed 5 March 2012) and data for India from the Ministry of Statistics and Programme Implementation (accessed 5 March 2012)

Regional inequality has also been a key contributor to total inequality in many Asian countries, particularly in the PRC and India (Figure 4.7). Notably for the PRC, in 1990-2003, regional inequality increased more or less concurrently with overall inequality.

In the PRC, there appears to be a general consensus that increased openness contributed to sharpening income disparities between coastal and interior regions. As Lin (2005) noted, an important feature of the country's global integration is the depth of concentration of international trade along the east coast - which has far lower transport costs to the country's major markets such as Hong Kong, China; Europe; Japan; and the United States. Since 2003, the PRC's regional inequality has declined somewhat. This has been partly attributed to the government's Great Western Development Strategy (Fan et al. 2011).

In India, coastal states have also fared better than inland states, although here a set of compounding factors including initial level of human capital and public infrastructure is also important (Kanbur et al. 2007). New private sector industrial investments typically take place in existing industrial and coastal districts to reduce costs, and overall investments have become more concentrated. 


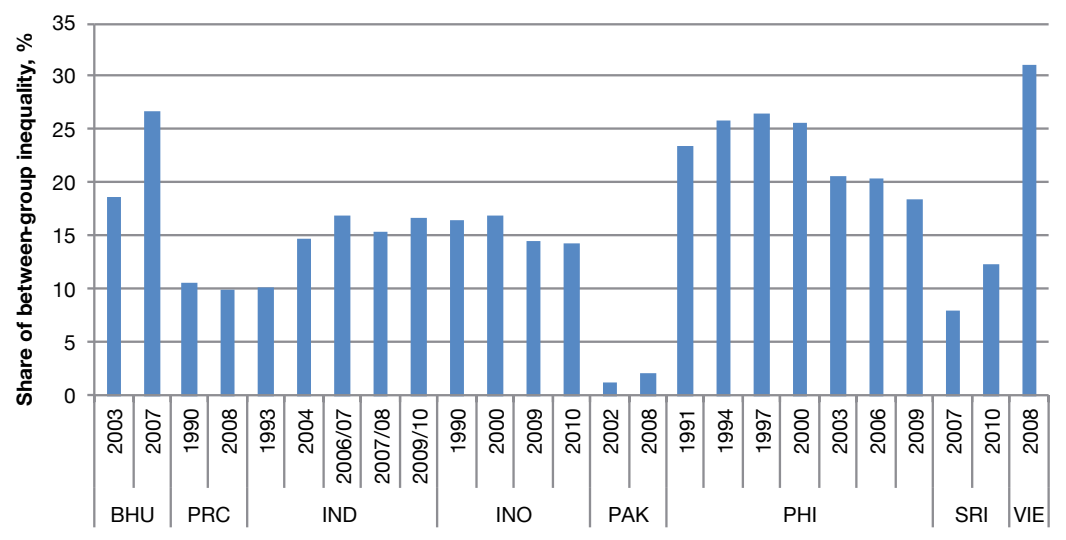

Figure 4.8. Income inequality decomposition, province/region

$\mathrm{BHU}=$ Bhutan, $\mathrm{PRC}=$ People's Republic of China, IND = India, INO = Indonesia, PAK $=$ Pakistan, $\mathrm{PHI}=$ Philippines, $\mathrm{SRI}=$ Sri Lanka, $\mathrm{VIE}=$ Vietnam.

Note. Estimates are based on per-capita expenditure in nominal terms. Decomposition is based on $\mathrm{GE}(0)$, which is a special form of the generalised entropy index.

Source. The author's estimates using household survey data

More generally, the interplay between market-oriented reforms and economies of agglomeration has given certain regions within countries an edge when it comes to economic growth. Indeed, this interplay has been linked to increasing inequality in South-East Asia and East Asia's middle-income economies (Gill \& Kharas 2007). Figure 4.8 provides decomposition results for regional inequality in selected Asian countries. Between-region inequality can explain 20-30 per cent of the national inequality in the late 2000s in Bhutan, the Philippines and Vietnam, and 10-15 per cent in the PRC, Indonesia, India, and Sri Lanka.

Combining the two components of spatial inequality and calculating the fraction of total inequality explained by rural-urban and interregional (provinces or states) divides, we see a share of more than half for the PRC (Figure 4.9). 


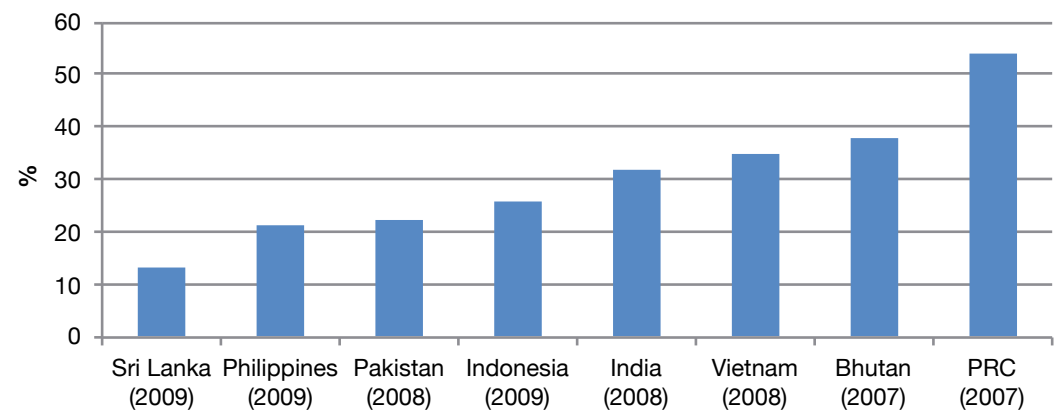

Figure 4.9. Combined contribution of spatial inequality to overall inequality in selected Asian countries

Note. Spatial inequality covers both between-region and urban-rural inequality. The estimation involves dividing all sample households into groups classified by both region and urban-rural. For example, if a country has 20 provinces, the total groups will be 40 (20 urban and 20 rural). The between-group inequality is the combined spatial inequality.

Source. The author's estimates using household survey data

In sum, the widening gaps between provinces and states, on the one hand, and between urban and rural areas, on the other, provide and will provide the geographic driver of inequality in Asia. These divides are important in themselves and because they account for a significant proportion of observed inequality in Asian countries. The driver of inequality in the spatial dimension is the interaction between new opportunities through trade, technology and market-oriented reform, interacting with the structure of geography and infrastructure. The rise in spatial inequality is not a reason to reverse openness and technological progress, or stop the reform process, but rather to reorient infrastructure investment to lagging regions, and to remove barriers to migration to the fast-growing regions.

\section{Widening wealth inequality}

Wealth distribution is usually more unequal than income distribution. Rising wealth inequality has likely also been a major contributor to the rising income inequality in the PRC, although it has not been studied as extensively as income inequality and other income inequality drivers, because of limited data. A recent study by Li and Wan (2015) finds that between 2002 and 2010, per capita household wealth (including land, housing, financial assets and other physical capital) increased by 4.1 times, and its Gini coefficient increased from 53.8 to 73.9. A major contributing factor to the rising wealth distribution has been rising housing prices. 


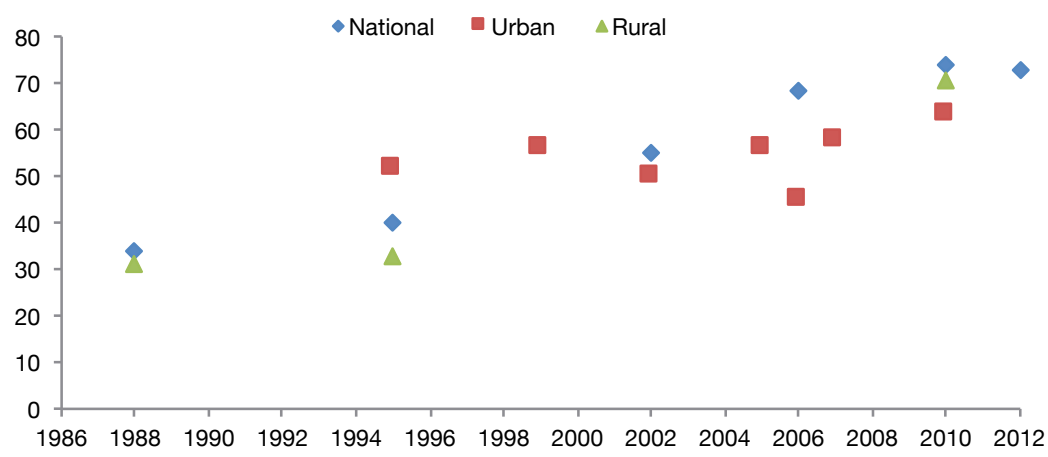

Figure 4.10. Gini coefficient of per capita net household wealth, PRC, 1988-2012

Source. Li \& Wan (2015)

Figure 4.10 plots various estimates of the Gini coefficient of per capita net household wealth from 1988 to 2012 for the entire PRC, urban PRC and rural PRC. It shows that wealth distribution has become more and more unequal in the PRC. For the PRC as a whole, the wealth Gini coefficient increased from 34 in 1988 to 73 in 2012. For urban PRC, it increased from about 50 in the mid-1990s to 63 in 2010. For rural PRC, it increased from 31 in 1988 to 71 in 2010.

\section{How to respond to rising inequality - promoting inclusive growth}

Because the forces behind rising inequality are also the engines of productivity and income growth, policymakers should not hinder their progress. A distinction needs to be made between the income differences that arise as economies and individuals take advantage of the new opportunities of technology, trade and efficiency-enhancing reforms; and those that are generated by unequal access to market opportunities and public services. This latter source of inequality requires a policy response because it is magnified by the driving forces of growth, leads to inefficiency and undermines the sustainability of growth. 
Based on these considerations, Zhuang and Ali (2010) propose an inclusive growth strategy to respond to rising income inequality in Asia. They define inclusive growth as 'growth with equality of opportunity', argue that an inclusive growth strategy should focus on both expanding economic opportunity and ensuring equal access to it, and that it should have the following policy pillars:

- sustaining robust economic growth. A large percentage of people in Asia are employed in the informal sector, and tens of millions of workers are set to join the region's labour force each year in the coming decades. Robust economic growth is needed for job creation. But to be inclusive, growth must provide decent, productive jobs for a wide spectrum of the population and expand economic opportunity for all

- promoting social inclusion. Every person must have equal access to opportunity. In many Asian economies, large portions of populations cannot benefit from economic opportunity created by growth for reasons beyond their control. Ensuring equal access to opportunity requires, on the one hand, investing in education and health care, especially for the disadvantaged, to enhance human capacities; and on the other hand, correcting market and institutional failures and eliminating social exclusion to level the playing field

- developing social safety nets. Programs are needed to mitigate the risks and vulnerabilities associated with transitory shocks to livelihoods that often are caused by ill health, economic crises, industrial restructuring, or natural disaster. Programs that cater to the special needs of the disadvantaged and chronically poor also are needed to prevent poverty

- mobilising more fiscal revenues. Greater spending on education and health and social protection programs requires Asian governments to mobilise more fiscal revenues to ensure fiscal sustainability. In many Asian countries, there is room for greater revenue mobilisation by improving tax administration and introducing taxes that are inherently progressive - such as those on capital gains, properties, and inheritance - that also help to reduce wealth inequality

- promoting good governance and sound institutions.

Each of the above pillars and their implementation must be supported by good governance and sound institutions. 


\section{Creating productive jobs through robust economic growth}

For the benefits of economic growth to be widespread, it must generate ample productive employment - the most important opportunity for human beings. Greater job creation will increase labour demand and hence labour's share in national income. Job creation, therefore, should be at the core of any country's inclusive growth strategy and at the top of its policy agenda. Achieving this goal in Asia remains a daunting task. An ADB Institute study (ADBI 2014) looked at the challenge of job creation in 12 Asian countries including China, India and 10 Association of Southeast Asian Nations (ASEAN) members, and found that more than half of their employment, amounting to 800 million people in total, can be classified as vulnerable under the International Labour Organization (ILO) definition. The study also showed that, between 2020-30, the combined labour force of these countries will expand by more than 10 million workers per year.

To create more jobs, Asian countries must maintain enabling environments for business investment and private entrepreneurship by eliminating impediments due to failures of markets, institutions and policies. This requires investment in physical infrastructure and human capital, development of institutional capacity, maintaining macroeconomic stability, adopting market-friendly policies, protection of property rights, and enforcement of the rule of law. In setting policy priorities, governments must identify the binding constraints to growth and target their efforts and resources to ease them. Governments should also pay attention not only to the pace of economic growth, but also to its pattern to ensure that it is broadly based (Ianchovichina \& Lundstrom 2009).

High growth will have to be driven by dynamic private sectors. But to attain full employment, the role of government will also be critical. Felipe (2009) proposes five sets of government policies to achieve full employment of the labour force. First, governments must redress the neglect of agriculture. Second, they should target high-employment public-investment projects in basic infrastructure such as energy, transport, and urban services. Third, they should collaborate with the private sector on policies to accelerate industrialisation and structural transformation. Fourth, governments should gear fiscal and monetary policies to the achievement of full employment. Fifth, they should devise job guarantee programs to ensure full employment with price stability. 


\section{Broadening opportunities by investing in education and health}

An effective way to reduce inequality and promote social inclusion is to enhance human capabilities, especially those of disadvantaged groups, by investing in education, health care, and other basic public services. Education improves labour productivity, facilitates technological innovation, increases return on capital, and helps improve health outcomes. Empirical studies find that basic education enables farmers to switch from traditional to more productive methods, and from farming to other more rewarding professions (Brooks et al. 2010). Similarly, good health can improve growth by boosting accumulation of human capital. The large gaps in education attainment and health indicators for many Asian countries compared with those of developed countries as well as differences within the region suggest Asian countries have much to do.

Governments - both central and local - have a critical role to play in investing in education and health because these services are public goods and have a strong external impact. In 2010, public spending on education was about 3 per cent of GDP for developing Asia as a whole, far less than the 5.5 per cent for Latin America and the Caribbean and 5.3 per cent for OECD countries; public spending on health was 2.4 per cent of GDP for developing Asia, compared with 3.8 per cent for Latin America and the Caribbean and 8.1 per cent for OECD countries (ADB 2014). Although public spending on education and health has increased in developing Asia in recent years, the gaps remain large.

In addition to providing adequate funding, governments should also ensure strong institutional capacity, sound policy frameworks, and good governance of health and education services. Governments also need to allocate resources equitably, such as among primary, secondary and tertiary schools and between primary health care facilities in rural areas, tertiary hospitals in cities, and prevention and treatment programs. Public investment must be complemented by supply-side policies to ensure the efficiency and quality of public services and demand-side policies to avoid moral hazard behaviour and waste. More innovative delivery mechanisms, such as the use of conditional cash transfers, non-government organisations in services contracting, and vouchers and contract teachers in delivering basic education services, can be explored to ensure that poor and disadvantaged groups are not excluded in accessing public services (Brooks et al. 2010). 


\section{Preventing poverty with social safety nets}

Inclusive growth also requires social safety nets that mitigate the effects of external and transitory livelihood shocks and meet the minimum needs of the chronically poor. Exposure to such risks can have a profound and long-lasting impact on human wellbeing. Social safety nets not only help the poor and vulnerable cope with the above risks, they can also play a role in improving human capital in the long run, which makes opportunities more accessible to those with limited assets and capabilities (Brooks et al. 2010). In 2010, public spending on social protection was 6.2 per cent of GDP for developing Asia as a whole, compared with 12 per cent for Latin America and the Caribbean and 20 per cent for OECD countries.

Social safety nets come in a variety of forms. Labour market policies and programs aim to reduce risks associated with unemployment, underemployment, or low wages that result from inappropriate skills in the workforce or poorly functioning labour markets. A range of socialinsurance programs, such as pensions and health or unemployment insurance, cushion risks associated with unemployment, ill health, disability, work-related injuries and old age. Social-assistance schemes such as welfare programs, social services, and cash or in-kind transfers are aimed at assisting single-parent households, victims of natural disasters or civil conflicts, the disabled, and other vulnerable groups. Other programs promote healthy and productive development of children by providing services such as early childhood development, school meals, scholarships, free or subsidised health care for mothers and children, and family allowances or credit (Ali \& Zhuang 2007). A growing body of empirical evidence suggests that social-protection schemes have significant impacts on poverty, inequality and human development (Skoufias 2001; Soares et al. 2006).

Targeting social protection programs toward the poor is a key issue for many Asian countries. Affordability is often raised as an issue when a country tries to expand safety nets. Yet studies assert that the costs of basic universal social protection are not beyond the reach of most developing countries (Ortiz \& Yablonski 2010). The United Nations Department of Economic and Social Affairs estimates that a universal social-pension scheme designed to keep the elderly above the $\$ 1$-a-day poverty line costs less than 0.5 per cent of GDP in most countries (UN 2007). Another study by the ILO argues that virtually all countries can afford some form of basic social security (ILO 2008). Affordability, therefore, may depend on a country's willingness to finance social-protection schemes. 


\section{Mobilising more fiscal revenues through tax reforms}

To increase public spending on education, health and social protection to enhance inclusion, and at the same time to ensure fiscal sustainability, Asia needs to expand and strengthen its fiscal revenue base. In 2010, total fiscal revenue as percentage of GDP was about 20 per cent for developing Asia, compared with 25 per cent in Latin America and more than 28 per cent for OECD (ADB 2014). Many governments in the region have made efforts to increase fiscal revenues through tax reforms, but more needs to be done.

Greater mobilisation of fiscal revenues requires exploring a range of options, including broadening the base for personal income tax and value-added tax (VAT), enlarging corrective taxes and nontax revenues, and introducing naturally progressive taxes on property, capital gains and inheritance. Broadening the base for personal income tax and VAT offers scope for raising more revenues by reducing various exemptions, deductions and tax incentives. For some Asian countries, lowering income thresholds for the higher tax rates can generate increased personal income tax revenues. Expanding VAT - or introducing one where it does not exist - generates revenue efficiently. Using additional revenues from VAT for public social spending can make this regressive tax progressive on balance. Corrective taxes and nontax revenues can promote efficiency and equity while raising revenue. Taxing property, capital gains and inheritance can make the tax structure more progressive and equitable.

\section{Strengthening governance and institutions}

Promoting good governance and sound institutions has been a key focus in development policy discussions in recent years and should also be a critical component of an inclusive growth strategy. Poor governance and weak institutions lead to unequal access to opportunities and public services, allow corruption and rent-seeking activities to prevail, and create social exclusion and injustice, all of which contribute to inequality. Good governance and sound institutions have intrinsic and instrumental value as they are a key precondition for sustained economic growth and prosperity (Acemoglu \& Robinson 2012).

Asian countries have made significant progress in strengthening governance and institutions in recent years. Going forward, a tailored approach to governance reform can be followed to maximise development impact. As development goals in themselves, all dimensions of governance 
should be pursued. But the stage dependency of the governancedevelopment nexus calls for prioritisation. Policymakers need to focus their efforts on the particular governance deficiencies that hold their country back from its next stage of development. Growth-supporting aspects of governance take centre stage for low-income economies. Strengthening government effectiveness, improving regulatory quality and rule of law, and scaling up control of corruption provide entry points to wider governance reform.

For middle-income economies, maintaining an environment supportive of growth is important, but policy must also respond to the rising aspirations of the populace. As their incomes improve and access to technology expands, citizens will demand greater say in national affairs. Moving to even higher income entails improving governance quality with respect to participation and accountability.

It is encouraging that more and more developing Asian countries are embracing the concept of inclusive growth, with an increasing number of countries - including the PRC, India and many South-East Asian countries - placing inclusive growth at the heart of their development policy, as reflected in their recent medium-term development plans. Indeed, the entire development community is embracing the concept of inclusive growth. These developments will go a long way toward reducing poverty and inequality and making the world a more equitable place.

\section{References}

Acemoglu, D (2002). 'Technical change, inequality and the labor market', Journal of Economic Literature, 40, 7-72. doi.org/10.1257/jel.40.1.7.

Acemoglu, D \& Robinson, JA (2012). Why nations fail. New York: Crown Publishers.

Ali, I \& Zhuang, J (2007). Inclusive growth toward a prosperous Asia: policy implications, ERD Working Paper Series, No. 97. Manila: Asian Development Bank.

Anand, S \& Kanbur, R (1993). 'Inequality and development: A critique', Journal of Development Economics, 41(1), 19-43. doi.org/10.1016/03043878(93)90035-L. 
Arpaia, A, Perez, E \& Pichelmann, K (2009). Understanding labour income share dynamics in Europe, MPR.000A Paper 15649. Germany: University Library of Munich.

Asian Development Bank (ADB) (2007). Key indicators for Asia and the Pacific 2007. Manila.

_ (2012). Asian development outlook 2012. Manila.

_ (2013). Asian development outlook 2013 update. Manila.

_ (2014). Asian development outlook 2014. Manila.

Asian Development Bank Institute (ADBI) (2014). ASEAN, PRC, and India: The great transformation. Tokyo.

Asian Productivity Organization (APO) (2011). APO productivity databook 2011. Tokyo: Keio University Press, Inc.

Attanasio, O, Goldberg, PK \& Pavcnik, N (2004). 'Trade reforms and wage inequality in Colombia', Journal of Development Economics, 74(2), 331-66. doi.org/10.1016/j.jdeveco.2003.07.001.

Autor, DH, Katz, LF \& Kearney, MS (2008). 'Trends in US wage inequality: Revising the revisionists', The Review of Economics and Statistics, 90(2), 300-23. doi.org/10.1162/rest.90.2.300.

Bai, C-E \& Qian, Z (2009). Factor income distribution: The story behind the statistics. People's Republic of China: Tsinghua University.

Brooks, DH, Hasan, R, Lee, JW, Son, HH \& Zhuang, J (2010). Closing development gaps: Challenges and policy options, No. 209, ADB Economics Working Paper Series. Manila: Asian Development Bank.

Card, D \& DiNardo, JE (2002). 'Skill-biased technological change and rising wage inequality: Some problems and puzzles', Journal of Labor Economics, 20(4), 733-83. doi.org/10.1086/342055.

de Groot, HLF, Poot, J \& Smit, MJ (2008). Agglomeration externalities, innovation and regional growth: Theoretical perspectives and meta-analysis, Working Paper in Economics, 01/08. Hamilton, New Zealand: University of Waikato.

Fajnzylber, P, Lederman, D \& Loayza, N (2002). 'Inequality and violent crime', Journal of Law and Economics, 45(1), 1-40. doi.org/10.1086/338347.

Fan, S, Kanbur, R \& Zhang, X (2011). 'China's regional disparities: Experience and policy', Review of Development Finance, 1(1), 47-56. doi.org/10.1016/ j.rdf.2010.10.001. 
Felipe, J (2009). Inclusive growth, full employment and structural change: Implications and policies for developing Asia. London: Anthem Press.

Felipe, J \& Kumar, U (2010). Technical change in India's organized manufacturing sector, Levy Economics Institute of Bard College Working Paper, No. 626. New York. doi.org/10.2139/ssrn.1691695.

Felipe, J \& Sipin, GC (2004). Competitiveness, income distribution, and growth in the Philippines: What does the long-run evidence show, ERD Working Paper?, No. 53. Manila: ADB.

Gill, I \& Kharas, H (2007). An East Asian renaissance: Ideas for economic growth. Washington, DC: World Bank. doi.org/10.1596/978-0-8213-6747-6.

Goldberg, PK \& Pavcnik, N (2007). 'Distributional effects of globalization in developing countries', Journal of Economic Literature, 45(1), 39-82. doi.org/ 10.1257/jel.45.1.39.

Harrison, AE (2002). Has globalization eroded labor's share? Some cross-country evidence, MPRA Paper, No. 39649, mpra.ub.uni-muenchen.de/39649/1/ MPRA_paper_39649.pdf.

Hsieh, C-T, \& Woo, KT (2005). 'The impact of outsourcing to China on Hong Kong's labor market', American Economic Review, 95, 1673-87. doi.org/ $10.1257 / 000282805775014272$.

Ianchovichina, E \& Lundstrom, S (2009). 'What is inclusive growth? A note supporting the diagnostic facility for shared growth', siteresources.worldbank. org/INTDEBTDEPT/Resources/468980-1218567884549/WhatIsInclusive Growth20081230.pdf.

International Labour Organization (ILO). (2008). Can low-income countries afford basic social security?, Social Security Policy Briefings Paper, 3. Geneva: ILO.

Jacobson, M \& Occhino, F (2012). 'Behind the decline in labor's share of income', Economic Trends. Federal Reserve Bank of Cleveland.

Kanbur, R, Gajwani, K \& Zhang, X (2007). 'Comparing the evolution of spatial inequality in China and India: A fifty-year perspective', Annual World Bank Conference on Development Economics (pp 155-77).

Kanbur, R \& Zhuang, J (2013). 'Urbanization and inequality', Asian Development Review, 30(1). doi.org/10.1162/ADEV_a_00006.

Kijima, Y (2006). 'Why did wage inequality increase? Evidence from urban India 1983-99', Journal of Development Economics, 81, 97-117. doi.org/10.1016/ j.jdeveco.2005.04.008. 
Krugman, P (2008). 'The increasing returns revolution in trade and geography', lecture delivered at Aula Magna, Stockholm University, 8 December, www.nobelprize.org/uploads/2018/06/krugman_lecture.pdf.

Kuznets, S (1955). 'Economic growth and income inequality', American Economic Review, 45, 1-28.

Lerman, RI \& Yitzhaki, S (1985). 'Income inequality effects by income source: A new approach and applications to the United States', Review of Economics and Statistics 67(1), 151-56. doi.org/10.2307/1928447.

Lewis, WA (1954). 'Economic development with unlimited supplies of labour', The Manchester School, 22(2), 139-91. doi.org/10.1111/j.1467-9957.1954. tb00021.x.

_ (1976). 'Development and distribution'. In A Cairncross \& M Puri (eds), Employment, income distribution and development strategy: Problems of the developing countries (Essays in honour of HW Singer) (pp 26-42). New York: Holmes \& Meier Publishers, Inc. doi.org/10.1007/978-1-349-81529-6.

Li, S \& Wan, H (2015). 'Evolution of wealth inequality in China', China Economic Journal, 8(3), 264-87. doi.org/10.1080/17538963.2015.1110338.

Lin, S (2005). 'International trade, location and wage inequality in China'. In R Kanbur \& AJ Venables (eds), Spatial inequality and development (pp 260-91). Oxford University Press.

Marquis, MH, Trehan, B \& Tantivong, W (2011). The wage premium puzzle and the quality of human capital, Working Paper 2011-06. Federal Reserve Bank of San Francisco.

Mehta, A, Felipe, J, Quising, P \& Camingue, S (2011). Where have all the educated workers gone? Services and wage inequality in three Asian economies, Working Paper, University of California - Santa Barbara, Global \& International Studies Program.

Nye, JVC (2014). 'Institutions and economic inequality in Asia: Disentangling policy and political structure'. In R Kanbur, G Rhee \& J Zhuang (eds), Inequality in Asia and the Pacific: Trends, drivers and policy implications (pp 156-72). London: Routledge and Manila: ADB.

Organisation for Economic Co-operation and Development (OECD) (2011). Education at a glance 2011: OECD indicators. Paris.

_ (2018). OECD.Stat database, stats.oecd.org. 
Ortiz, I \& Yablonski, J (2010). 'Investing in people: Social protection for all'. In SW Handayani (ed.), Enhancing social protection in Asia and the Pacific: Proceedings of the regional workshop (pp 36-56). Manila: Asian Development Bank.

Ozler, B \& Demombynes, G (2002). Crime and local inequality in South Africa, World Bank Policy Research Working Paper, No. 2925. Washington DC: World Bank.

Robbins, DJ (1996). Evidence on trade and wages in the developing world, OECD Technical Paper, No. 119. Paris.

Rodrik, D (1997). Trade, social insurance, and the limits to globalization, NBER Working Papers, 5905. National Bureau of Economic Research, Inc. doi.org/ $10.3386 /$ w5905.

Sanchez-Paramo, C \& Schady, NR (2003). Off and running? Technology, trade, and the rising demand for skilled workers in Latin America, World Bank Policy Research Working Paper, 3015. Washington, DC: World Bank. doi.org/ 10.1596/1813-9450-3015.

Skoufias, E (2001). PROGRESA and its impact on human capital and welfare of households in rural Mexico: A synthesis of the results of an evaluation by IFPRI. Washington, DC: International Food Policy Research Institute.

Soares, FV, Soares, S, Medeiros, M \& Osório, RG (2006). Cash transfer programmes in Brazil: Impacts on poverty and inequality, IPC Working Paper, No. 21. Brasilia: International Poverty Centre.

Son, HH (2010). 'Growth, inequality, and the labor market: The Philippines'. In J Zhuang (ed.), Poverty, inequality, and inclusive growth: Measurement, policy issues, and country studies (pp 58-78). London: Anthem Press and Manila: ADB.

- (2012). Inequality of human opportunities in developing Asia, ADB Economics, Working Paper No. 328. Asian Development Bank. Manila.

United Nations (UN) (2007). Development in an ageing world: World Economic and social survey 2007. New York: United Nations.

World Bank (2012). Is higher education meeting its promises? Putting higher education to work: Skills and research for growth in East Asia, East Asia and Pacific Regional Report. Washington, DC.

World Values Survey (2005). www.worldvaluessurvey.org/WVSDocumentation WV5.jsp. 
Zhuang, J (1996). 'Estimating distortions in the Chinese economy: A general equilibrium approach', Economica, 63(252), 543-68. doi.org/10.2307/ 2554995 .

— (ed.) (2010). Poverty, inequality, and inclusive growth: Measurement, policy issues, and country studies. London: Anthem Press and Manila: ADB.

Zhuang, J \& Ali, I (2010). 'Poverty, inequality and inclusive growth in Asia'. In J Zhuang (ed.), Poverty, inequality, and inclusive growth: Measurement, policy issues, and country studies (pp 1-32). London: Anthem Press and Manila: ADB.

Zhuang, J, de Dios, E \& Lagman-Martin, A (2010). 'Governance and institutional quality and the links with growth and inequality: How Asia fares'. In J Zhuang (ed.), Poverty, inequality, and inclusive growth: Measurement, policy issues, and country studies (pp 268-320). London: Anthem Press and Manila: ADB.

Zhuang, J \& Shi, L (2016). Understanding recent trends of income inequality in the People's Republic of China, ADB Economics Working Paper Series, No. 489. Manila, ADB. 
This text is taken from Achieving Inclusive Growth in the Asia Pacific, edited by Adam Triggs and Shujiro Urata, published 2020 by ANU Press, The Australian National University, Canberra, Australia.

doi.org/10.22459/AIGAP.2020.04 